\title{
The Division of Israel's Monarchy and the Political Situation of Lesotho
}

\author{
S Fischer \\ (Morija Theological Seminary)
}

\begin{abstract}
\end{abstract}
This article deals with the Old Testament's depiction of the historical developments that led to the division in Israel's monarchy. It presents the underlying factors that destabilised the country during the lifetimes of David and Solomon as well as the power-play between Rehoboam and Jeroboam. The political developments in Lesotho are then read against these underlying factors.

\section{INTRODUCTION}

Saul was Israel's first king. His kingship was of a primitive kind (Fensham \& Pienaar 1989:96) in which the king functioned as a military leader rather than as a King. Saul's reign was followed by that of David and Solomon. They were the only Israelite kings who ruled over both the northern and southern kingdoms in a personal union (Alt 1964:117) commonly called the monarchy. David reigned for 33 years over all twelve tribes (2 Samuel 5:5). He was succeeded by Solomon, who reigned for 40 years after being crowned as king when the aged David was still alive (1 Kings 1:32-48). The monarchy lasted for about 70 years and came to a sudden end after Solomon's death.

Even though the kingdom was divided at that time, the roots of this division may be traced far back into the history of Israel. In part, the division resulted from David and Solomon's tailor-made monarchy as well as the developments that took place after the death of Solomon. In this article, I distinguish fifteen underlying factors that influenced the division of Israel's monarchy. Each of these underlying factors has impacted upon the history of Israel with various degrees of intensity. At times, they were initiated for the sake of the nation, whilst at other times they were driven by egoistic motives. Be that as it may, the result was a national disaster that was never overcome in Israel's history. Nevertheless, the hope of a reunited monarchy remained alive for the envisioned glorious, eschatological future (Ezekiel 37:15-28) ${ }^{1}$.

As previously indicated, I have discerned 15 factors that contributed to the division of the Israelite monarchy. These are discussed in section 2. below. In my opinion, relating these factors to the situation in Lesotho

\footnotetext{
${ }^{1}$ According to Stuhlmacher (1997:83), it was a messianic symbolic act that Jesus called twelve disciples, signifying his claim for the twelve tribes of Israel, because the reestablishment of the twelve tribes of Israel was seen as God's saving act at the beginning of the messianic age.
} 
today will enable us to draw valuable comparisons that will benefit Lesotho's future peace and prosperity. I therefore present important events in Lesotho's history, her people and structures for comparison in section 3.

\section{FIFTEEN FACTORS THAT UNDERLIE THE DIVISION OF THE ISRAELITE MONARCHY}

\subsection{Continuous antagonism and power struggle between various tribes}

Pre-monarchic Israel did not begin as a homogeneous nation. It became a nation over a long period of time. The Biblical narratives recall how the nation evolved through the joining of diverse groups of people (Exodus 12:38; Judges 1:16). They were a "mixed group, by no means all descendants of Jacob” (Bright 1981:134). They did not gather around one sacral (sacred) place as a twelve-tribe amphictyony, as Noth (1959:86-91) had suggested. Modern scholarship favours different models for Israel's early history but agrees that diverse groups formed the later nation (Lemche 1988:88-109). The rivalry between the tribes and their different history in pre-monarchic times may reflect an ethnic and political division (Soggin 1984:41) that was probably supported by religious diversity. Sporadical calls for a monarchy were generally rejected. They were either abandoned immediately (Judges 8:22-23), or rejected after a short period of time (cf. Judges 9:22-23ff).

According to the book of Judges, whilst some tribes formed coalitions, they also turned against each other at various times (cf. e.g. Judges 20). Furthermore, not all tribes were held in the same esteem. For example, antagonism seems to have been directed against the Ephraimites in particular, as Judges records two occasions where they complained that they had not been asked to join a battle (Judges 8:1-3; $12: 1-6)^{2}$.

When Saul was made king, he took up the charismatic role of the judges (Alt 1964:118). His kingship did not constitute a centralised monarchy with the hegemony of one tribe. Rather, Saul had been chosen as king to act as an elected military leader on a permanent basis (Bright 1981:190). This was done because of the constant threat posed by the Philistines, the nomads of the desert, and the Canaanites (Donner 1984:173; Lemche 1988:135-138). He struggled throughout his reign to stabilise Israel but failed. At the time of his death, he left behind a country in crisis (Lemche 1988:125). When David became king, the kingship was transferred from the tribe of Benjamin to that of Judah. There was no

\footnotetext{
${ }^{2}$ The tribe of Ephraim had never been well-accepted, but demanded a superior position. Later, in the Northern Kingdom, Ephraim's superior position is still evident. Ephraim is even used synonymously for Israel (2 Chronicles 25:7; Isaiah 7:2).
} 
reason for all the tribes to accept David as king immediately, as kingship was still foreign to Israel, and its implications still undefined. David faced opposition from the leader of Saul's army, Abner, who was related to the king's house (1 Samuel 17:20). He supported Ishbaal, the son of Saul, and made him king. Ishbaal lacked the people's support because he did not fulfil the original expectation of a king, that is being a successful military leader (Donner 1984:187).

As a result of Philistine dominion, David initially ruled over a very limited kingdom, viz. the Transjordanian territory. The tribes of Gilead, Ephraim, and Benjamin as well as the people of Jezreel, a city in Issachar and the Ashurites in the main supported Ishbaal (2 Samuel 2:8-10). It was only after Ishbaal's assassination (2 Samuel 4:7) that David gained control over all Israel (2 Samuel 5:1-3), uniting the royal office of two kingdoms (Donner 1984:194), namely Israel and Judah (2 Samuel 5:5; 11:11), in a personal union.

Sheba's revolt took place during David's reign. Sheba was a member of Saul's tribe and had been living in Ephraim (2 Samuel 20:21). He might have hoped to get tribal support from the Northern tribes, who were negative towards David's monarchy (Donner 1984:214). Sheba's war-cry (2 Samuel 20:1) is almost identical with the one of the secessionists under Rehoboam (1 Kings 12:16; Soggin 1984:65). The narrator clearly prepares his case that the disunity and constant animosity of the Northern tribes was a major factor of the schism.

\subsection{Disunity in the Army}

Abner had been the commander-in-chief of the army under the reigns of Saul (1 Samuel 14:50; 17:55) and Ishbaal (2 Samuel 2:8). During Ishbaal's reign, David had already formed a new army whose members came from Judah. There were two chief commanders in the army, one for Judah and one for Israel. "Abner son of Ner, was commander of the army of Israel, and Amasa son of Jether, was commander of the army of Judah" (1 Kings 2:32). After David had established the monarchy, he took the co-ordination of these two armies under his control (Donner 1984:203). He created a new office and put Joab, his faithful friend, in control of the army (2 Samuel 8:16).

\subsection{The extended influence of the royal family weakened the distribution of power}

The power of the kingdom was maintained through the extended influence of the royal family. The latter occupied the important positions in the government and elsewhere. For example, David made his nephews (1 Chronicles 2:16.17) commanders of the army. First Joab and later Amasa, 
the son of David's sister Abigail (1 Chronicles 2:16.17), commanded the army of Judah (2 Samuel 8:16; 19:13). David's ally and intimate friend was his brother-in-law Jonathan (1 Samuel 18:1-4). David had a group of bodyguards and heroes led by his nephew Abishai (2 Samuel 23:18).

Eliminating legal opposition and religious independence had weakened the distribution of power. Samuel, who had been judge and prophet, had opposed Saul with prophetic and legal power. He was a judge who had the power to anoint and appoint a new king. With his death, this office vanished. Instead, we find that Nathan, a prophet, did not have any legal powers. He could only warn David by raising his prophetic voice. Whilst Samuel rebuked Saul because he took it upon himself to offer sacrifices (1 Samuel 13:4-15), David was not rebuked when he acted as a priest by taking the holy bread (1 Samuel 21:6), offering sacrifices and blessing the people in the name of the Lord (1 Chronicles 16:2).

\subsection{The monarchy was maintained with foreign troops and aid}

David had a special force of people originating from the seacoast, the Cherethites and the Pelethites (2 Samuel 20:7). Solomon added horsemen and chariots (1 Kings 5:6), which he most likely recruited from among the Canaanites (Donner 1984:198). He could expect higher loyalty from people who had no personal interest or family involvement in the political matters. Solomon's building projects, the temple, palace and fortresses had been built with the help of foreign workers, building material and cash (1 Kings 5:10-18; 9:11,14). In the beginning, Solomon had managed to pay him. Gradually, he became more indebted to Hiram than he had anticipated. As payment Solomon gave Hiram twenty towns but this was an inadequate payment that did not please Hiram (1 Kings 9:11-13).

\subsection{Religious disunity: Two priestly families}

The position of the religious leaders was weak because of their disunity. Two priestly families were in competition, even if they worked partly together. Abiathar was from the line of Eli. After his father, Ahimelech, had been murdered at Nob (1 Samuel 22:16-21), he joined David (1 Samuel 30:7). As David became king of Judah he made Abiathar high

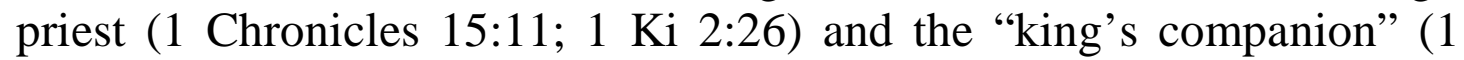
Chronicles 27:34). On the other hand, Zadok, from the line of Eleazar, who had been a son of Aaron (1 Chronicles 6:50-53), was priest (2 Samuel 20:25; 1 Kings 4:4). He descended from a family with a long genealogical tradition and historical influence. This disunity might have given rise to David bringing the priesthood under the control of the royal family. It was not a priest, but David who brought the ark into Jerusalem (2 Samuel 6), even if Zadok was in charge of the ark and Abiathar made 
sacrifices (2 Samuel 15:24-29). David chose the temple area (2 Samuel 24:24). Solomon built the temple and inaugurated it (1 Kings 6-8). David and Solomon influenced the priestly appointments, for example David made his sons priests (2 Samuel 8:18). They could intervene in the appointment or discharge of priests. Abiathar had supported Adonijah in his claim to the throne (1 Kings 1:7). Therefore, Solomon "banished Abiathar from being priest to the Lord, thus fulfilling the word of the Lord that he had spoken concerning the house of Eli in Shiloh" (1 Kings 2:27).

\subsection{The voice of the people was silenced}

Like the judges, Saul received his authority through the call of Yahweh (1 Samuel 9:1-10:16). Even if Samuel anointed Saul as king because of his divine election, the affirmation and agreement of the people was needed (1 Samuel 11:14,15). Likewise, Samuel anointed David as a successor of Saul (1 Samuel 16:1-13), but it needed a compact with the elders of Israel to make David king over the whole of Israel (2 Samuel 5:3). Later on David made Solomon king over both kingdoms (1 Kings 1:32-35) without even mentioning the people (Alt 1964:120). The role of the people was only to accept whom the monarch had chosen.

\subsection{Power struggles - No clear rules for succession and the late appointment of a successor}

The succession struggle under David (2 Samuel 15-20; 1 Kings 1) shows that no clear rules of succession had been made. The idea existed that the oldest son would be the heir to the throne. This is evident from Ishboshet (Eshbaal) succeeding Saul (2 Sam 2:8-10) as well as from the succession struggle in David's family during his lifetime. The list of David's sons (2 Samuel 3:2-5) provides their order. David's oldest son was Amnon. He is the one who raped his half sister Tamar and was later killed by his half brother Absalom in revenge (2 Samuel 13). David's second son Chileab, who was also called Daniel (2 Samuel 3:3; 2 Chronicles 3:1), is never mentioned elsewhere. He probably died at an early age. The next two sons, Absalom (2 Samuel 15-18) and Adonijah (2 Kings 1), also tried to come to power, but failed. Their influence had been strong because important officials had sided with them. David even had to leave Jerusalem to flee before Absalom (2 Samuel 15) and could only return after his tragic death (2 Samuel 18). These power struggles evolved because no clear rules of succession had been made, and a successor had not been appointed in time. David was already very old when he appointed Solomon as his successor. The fact that he waited too long encouraged his sons to try and take over (Donner 1984:210). The succession was only solved as David used his authority to announce Solomon as king (1 Kings 1:32-34). Later Solomon did the same. He did 
not look for any co-regency with his son. It seems that it had been communicated to the people that Rehoboam would be the heir on the throne but his coronation took place only after the death of Solomon (1 Kings 11:43-12:1).

\subsection{Suppression of opposition leads to an exile of people}

The time of Solomon is described as a time of peace and safety for the nation (1 Kings 5:5). During his reign Solomon had kept dissatisfied people silent. He was so well established in his position that an opposition could not rise up. In his old age he could not defeat all his adversaries but he could keep them out of his country. He had faced three direct enemies: Hadad of Edom, Rezon of Damascus, and Jeroboam, who later became king of the Northern Kingdom (1 Kings 11:14-26). As Solomon rebuked Jeroboam, whom he had once entrusted with the "charge over all the forced labour of the house of Joseph (1 Kings 11:28), he fled to Egypt and waited for his chance, which came after Solomon's death (1 Kings 12:2). In exile he planned his return and sought the support of the Egyptians. The empty throne gave the opposition party new impetus. Presumably, the king of Egypt intended to increase his influence over an area that had formerly been under Egyptian control. The Pharaoh had established good relationships with Solomon's enemies. He had granted Hadad (1 Kings 11:17,18) and Jeroboam (1 Kings 11:40) refuge. Further he had given Hadad his sister-in law in marriage (1 Kings 11:19).

\subsection{Divine assurance by prophetic encouragement}

As Jeroboam fled to Egypt he met the prophet Ahijah, who encouraged him with a prophetic word that he would become king over ten tribes of Israel (1 Kings 11:30,31). Such divine assurances are not forgotten (1 Kings 14:2), and have motivated people through the ages. It seems that this prophetic message had been spread among the people of Israel and encouraged them to dissociate themselves from Rehoboam (1 Kings 12:15,16).

\subsection{Polygamy and religious idolatry}

Solomon had entered many marriage-contracts to establish stable political conditions. His polygamy led to religious apostasy. The loss of the kingdom is seen as God's punishment for Solomon's religious idolatry (1 Kings 11:31-35).

\subsection{Kingdom instability as a result of alienating the people}

Rehoboam had inherited an unstable kingdom that based its glory on increased taxes and forced labour for the Israelites (1 Kings 5:13). Solomon had extended his father's system of forced labour (2 Samuel 12:31) from the Canaanites (1 Kings 9:20.21) to the Israelites (1 Kings 5:27) (Donner 
1984:205) $)^{3}$. These were people from the Northern tribes, as can also be seen from the reaction of the Northern tribes at Rehoboam's coronation (1 Kings 12:4,10; Donner 1984:223 n.36). This policy became Rehoboam's stumbling block.

\subsection{Seeking the people's favour}

After the death of Solomon, his son Rehoboam was seen as the legal heir by the Southern tribes (1 Kings 11:43). The Northern tribes did not take this for granted, particularly as they felt that they had not been treated equally. Rehoboam realised the lack of support, but he needed their special approval and confirmation if he wanted to be a king of all. His intended coronation in Shechem might reflect the dualism of the kingdoms, each kingdom crowning its own king (Soggin 1984:192). It seems as if Shechem was not chosen by Rehoboam but on the insistence of the Northern tribes (1 Kings 12:1) (Rice 1990:98). Shechem was a place with historical significance for Israel. All the tribes of Israel had gathered there and renewed the covenant under Joshua (Joshua 24:1). It had probably served as an administrative capital (Soggin 1984:192). Rehoboam sought the favour of the Northern tribes too late. Jeroboam had already made his preparations. Immediately after the death of Solomon he returned from exile and became the spokesman of the people (1 Kings 12:3).

\subsection{A weak and insensitive leader with the wrong advisors}

When Jeroboam came to Shechem for the coronation of Rehoboam (1 Kings 12), Rehoboam acted as a weak and insensitive leader. Rehoboam accepted Jeroboam as spokesperson instead of taking action against him as Solomon had attempted (1 Kings 11:26-40). He listened to Jeroboam and representatives from the ten tribes who requested him to reduce taxation (1 Kings 12:4). The old advisors were experienced men who had stood up to Solomon (1 Kings 12:6). They advised Rehoboam to accept the request of Jeroboam and the elders and reduce taxation. This would have been understood as a sign of goodwill. Instead, Rehoboam threatened to increase taxation and forced labour. This announcement was based on the advice of some young men $^{4}$, who had grown up with him, and were dependent on the

\footnotetext{
${ }^{3}$ Solomon is taking the Israelites into forced labour (1 Ki 5:27) is in conflict with $1 \mathrm{Ki} 9: 22$ : "Of the Israelites Solomon made no slaves”.

${ }^{4}$ If they are called "young men” we should be reminded that Rehoboam, according to the chronology of Kings, was already 41 years old when he became king (1 Kings 14:21). Hence the term "young men" doesn't refer to their actual age but how they are judged in the eyes of the writer of the book of Kings. They act like young men contrary to Solomon's old advisors. Rehoboam's young advisors show their foolishness by boasting in a sadistic and obscene manner. They suggest that Rehoboam should threaten the people with aggressive slogans such as "I will discipline you with scorpions" (1 Kings 12:11), and "Thus you should say to this people who spoke to you, "Your father made our yoke heavy, but you must lighten it for us'; thus you should say to them, 'My little one is thicker than my father's loins"” (12:1). The 'little one' is a euphemism for the "little one" only men have. His father's loins are the place of sexual potency (Nelson 1987:79; Soggin 1984:194). We have here a sexual proverb typical of immature young men.
} 
new regime (Nelson 1987:78). His answer devaluated the voice of the people. That caused the break off of the ten tribes:

"When all Israel saw that the king would not listen to them, the people answered the king, 'What share do we have in David? We have no inheritance in the son of Jesse. To your tents, O Israel! Look now to your own house, O David.' So Israel went away to their tents” (1 Kings 12:16).

\subsection{Rehoboam overestimated his power}

After the ten tribes had spoiled Rehoboam's coronation he became afraid and "hurriedly mounted his chariot to flee to Jerusalem" (1 Kings 12:18a). Still, he overestimated his power and expected to get the situation under control. Therefore he sent "Adoram, who was taskmaster over the forced labour" but as he arrived he was rebuked and "all Israel stoned him to death" (1 Kings 12:18b).

\subsection{Raising the prophetic voice}

Rehoboam thought of saving the monarchy by using force. He attempted to gather all the people of Judah and Benjamin, who were able to go into war, to fight in the civil war against the ten tribes. This battle did not take place, because of the individual courage of the prophet Shemaiah. He made a public speech with an immense effect: "Thus says the Lord, 'You shall not go up or fight against your kindred the people of Israel. Let everyone go home, for this thing is from me.' So they heeded the word of the Lord and went home again, according to the word of the Lord” (I Kings 12:24).

\subsection{Theoretical implications}

When comparing historical developments in ancient Israel with the present situation in Lesotho, we must take into account that these two nations are separated by culture, time and distance. Nevertheless, the present political situation in Lesotho is also deeply rooted in the country's history, and evinces the same patterns and power struggles that evolved in ancient Israel.

These fifteen factors presented differ in importance. Some are more obvious factors, while others demonstrate more general weaknesses within the system. Their negative influence on the monarchy only came into effect because of the decline of the monarchy. All of them contributed to the loss of the monarchy. It was not merely a single factor that brought about the decline. It was a single incident that led to the loss of the monarchy, namely the coronation in Shechem. Even there, it was not the single incident of not reducing the taxation. This was the last straw, but it would not have had its impact if Rehoboam were well established as king. In that case, the Northern 
tribes could not have broken off that easily; that Rehoboam listened to the wrong advisors would not have had such a devastating effect. These fifteen multifarious interdependent factors, as well as lucky chance and unfortunate accident make up history. If we now turn to the history of Lesotho, we must be aware that the fifteen factors presented are basic patterns that reoccur in the history of Lesotho. There are, of course, fundamental differences between an ancient monarchy and a modern democratic state, but they do not rule out these factors. Furthermore there will be other factors that were fostered by different circumstances. It is not an oversimplification to state that both agree in having a king, and get the people somehow involved in the process of decision making. It is a pattern built on the same patterns, but lays stress on different factors.

It is the task of an academic to present facts and developments without taking sides. This kind of objectivity will never be free from personal convictions even if the distance to the time of the Israelite monarchy might have helped me to present a fairly objective analysis. In the next paragraph I present my assessment of the historical developments that led to the political situation of Lesotho.

For a better understanding of Lesotho's history the reader is referred to the bibliography used. The numbers in square brackets refer back to the first part, showing the point of comparison.

\section{THE POLITICAL SITUATION OF LESOTHO IN THE LIGHT OF ISRAEL'S DIVIDED KINGDOM}

Among the Basotho kings are not elected, but descend from the royal family [6]. Mohlomi, the chief, diviner and healer (c. 1720-1815), who had the later king Moshoeshoe I (before 1786-1870) as his disciple, was religiously motivated (Gill 1993:59-62). He got divine assurance [9] through a dream, where he met his ancestors who promised him that he would be a king (Machobane 1978:21). The first king of Lesotho, Moshoeshoe I, had observed the struggle and competition between the three sons of his first wife, and saw it as a threat to the unity of the nation (Gill 1993:110-111). He tried to create clear rules of succession [7] by clever marriage contracts. His polygamy [10] was part of his politics. Moshoeshoe I married many wives from leading families who were spread all over the country (Gill 1993:85). Some worshipped a god through their ancestors whilst others worshipped idols [10]. These differences in worship led to an indecisiveness that affected the Christian commitment of the Basotho. Moshoeshoe I united different tribes under his leadership but established a system of superiority of his own people. Until today there are more and less important tribes. A subtle animosity remains [1]. This is even more obvious in the South, where some Xhosa-speaking groups live. 
During the reign of Moshoeshoe I, the first missionaries were called into the country. They were reformed, French men of the Paris Evangelical Missionary Society. Even if their beginnings were not easy and their ministry made only little progress, it was a soli uno witness of the gospel. Unfortunately, the disunity of the European churches, which had their theological conflicts as well as power struggles, destroyed the Christian unity [5] with the arrival of Roman Catholic and Anglican missionaries.

The legend about Moshoeshoe It's baptism reveals his aims. It is said that he wanted to be baptised by missionaries from the Protestant, Roman Catholic and Anglican churches ${ }^{5}$ at the same ceremony. He had rightly observed the rivalry between the denominations [5] and was afraid that his baptism would divide the nation (Gill 1993:112). When Moshoeshoe I died he was still "unbaptized and more than likely unconverted" (Machobane 1993:28). All his life he had used the church for his own purposes.

In 1912 Roman Catholic missionaries succeeded in converting the king Letsie II, and establishing a close link [3] between the Roman Catholic Church and the king's family.

Until today, power struggles within the royal families and debatable rules of succession are symptomatic for the successors of Moshoeshoe I [7]. During his reign (1870-1891) Moshoeshoe's son Letsie had to face the opposition of his brothers Molapo and Masopha, who controlled the northern part of Lesotho and strove for as much autonomy as possible. They "used their wealth and influence through institutions such as mafisa, tribute labour, polygamy and the placing of relatives over outlying areas" (Gill 1993:116) [11,10,3]. Power struggles from within the family, as well as from the outside (Gill 1993:143), continued as Letsie's son Lerotholo (18401905) succeeded him (1891-1905). Lerotholo's son Letsie II (1870-1913) needed the support and confirmation of the British High Commissioner in order to be installed as king. Even as king governmental affairs were with his uncles (Machobane 1990:103) [3]. After the death of Letsie II, his only son Tau died under mysterious circumstances. In 1913, after complex negotiations (Gill 1993:159), Letsie's younger brother Nathanael Griffith Lerotholi (1871-1939) became king. The installation of his son Seeiso Griffith (1904-1940), who ruled only for one year, was also controversial [7]. After his untimely and also mysterious death it was not his brother but his principal wife 'Mantšebo who was made chieftainess by the resident commissioner and most of the principal chiefs. She ruled for twenty years (1941-1960). When in 1960 Constantinus Bereng Seeiso (1938-1969) became king as Moshoeshoe II, he was still very young, only 22 years old.

\footnotetext{
${ }^{5}$ The Anglican Church entered Lesotho only in 1876 through the English Church Mission (Mohapeloa 1985:2) but Moshoeshoe I had been in contact with Anglicans since the 1850. He sent three of his sons to them for education (Gill 1993:137).
} 
He had to face some opposition because his claim for the throne was subject to some dispute [7]. He was the first son of the second wife of his father Seeiso Griffith, and he had older brothers born out of wedlock (Gill 1993:186). Already in 1957, people had called for the installation of the king. In 1959 the constitution laid down limited powers of the king. For those who wanted a strong monarchy, Moshoeshoe II too late became king. The power was handed over too late[7]. Preparations were already on their way for an independent and democratic Lesotho, with a monarch whose constitutional powers would be very limited. Nevertheless, the royal family remained very influential [3]. In any district the one who has power belongs to the family of Moshoeshoe I, that is the clan Bakoena of Mokoteli.

Power struggles [7] have been characteristic of the politics of Lesotho. In 1970, when Dr. Ntsu Mokhehle of the BCP won the elections, chief Leabua Jonathan (BNP), who had the royal support announced the elections failure, suspended the constitution and imprisoned members of the opposition. He overruled the will of the people [6]. On this occasion the Lesotho Evangelical Church raised her independent, prophetic voice [15], issuing a statement "Lentsoe la Kereke" (The Voice of the Church), appealing for justice, peace, and keeping the constitution (Mohapeloa 1985:59).

The neighbouring country [4] South Africa, supported Jonathan in the fight against the guerrilla fighters. The military regime of Jonathan could suppress opposition [8] for a long time, but until today the treatments of that time has alienated many people [11] from his party.

Repeatedly, through dictatorial leadership, dissatisfied people have been silenced [8]. In 1974, after an alleged coup of the opposition, several members were imprisoned or killed. Dr. Mokhehle (BCP) and others fled into exile [9]. In 1993, after his return [9], he became Prime Minister, when the first free elections since 1970 were held.

Nepotism [3] continued in the Lesotho government. In 1986, as Moshoeshoe II and Major General Lekhanya ruled, family members (e.g. Sekhobe Letsie, Thabe Letsie, Ngoana Ntloana Lerotuli) occupied the ministries of the government. This caused problems in the area of employment. People gave the jobs to their relatives. The royal influences extended also to the army, where family members had been on the military council (Gill 1993:242). In 1990 this led to problems in the army [2], which was only overcome when General Lekhanya, the chief commander of the army, expelled those family members. After Moshoeshoe II had tried to extend his control [3], Lekhanya incited a coup and forced him into exile. In 1991 Lekhanya was sacked. His deputy Elias Phisoana Ramaema deprived him of his power. Ramaema gave way to free elections. He also announced a $20 \%$ increase in salaries for the soldiers, teachers and civil 
servants (Gill 1993:245). This was in order to gain the favour of the people [12].

After Moshoeshoe II had been deprived of power, the principal chiefs brought Letsie III (*1963) into power (Gill 1993:243). In 1995 Moshoeshoe II was reinstalled after Letsie III had failed in an attempted coup d'état to gain more power (Ploetz 1998:1688). This reveals power struggles within the royal family [7]. When Moshoeshoe II died in 1996, his succeeding son Letsie III had to struggle for power. After his coronation in November 1997 the tribal clans complained [1, 15] that the monarchy is constantly kept among the sons of Moshoeshoe (Leselinyana 30.11.1997).

The elections in 1998 divided the nation. Some people's struggle for power made it impossible for them to accept the outcome of the elections. In that tense situation the Executive Committee of the Lesotho Evangelical Church published a statement, headed "We shall not remain silent". It addressed the political situation in Lesotho, and called for the acceptance of the free and fair elections. The politicians were called to be cautious: "Beware politicians that the blood of many Basotho has been spilled in the name of your politics. Beware again that your actions, which have resulted in the death of many Basotho, are contrary to God's commandments which say. 'Thou shall not kill', and 'Thou shall love your neighbour as yourself'”. The letter is headed with a quotation from the prophet Isaiah (58:1a). By doing so the LEC justified its action as being the prophetic function [15] of the church.

Unfortunately, this did not avert the political unrest in September 1998. The failure of those who instigated the burning and looting of Lesotho to take over the government shows that they overestimated their power [14]. During this time Letsie III opened the gates of the palace and let the demonstrators in. By doing so he took side. He upset many people and weakened his position as a unifying person of the country. Was he a sensitive leader? Did he have the right advisors [13]?

The present political situation of Lesotho remains unstable but enjoys relative peace. This has been established with the help of the foreign troops [4] of SADC. The aim of all political discussions must be to foster a democratic government that is accepted by the people and not sustained by foreign troops or aid [4]. Until now this has not been achieved. Major political parties are paralysed as a result of the internal power struggles after their leadership had been handed over too late [7]. Parts have broken off and new parties have been formed. It has not yet become evident if the new and old leaders mainly serve for the sake of the nation or pursue their own political interests. Also the failure of the National Assembly Business Committee to deliberate the recent motion of the Lesotho People's Congress 
(LPC) against the "Interim Local Government Councils" points at the internal struggles. Not only in the ruling party, but also in the present IPA (Interim Political Authority), the egotistic interests of staying in office as long as possible - to benefit from the generous monthly salaries - prolong the preparations for elections and their repeated postponement. At one stage, the IPA proposed that people who might be Council of State should be between 45 and 65 years of age. By this the majority of the people would have had no part in their government [6]. It would only be a gain for older people (Mantloane oa Maqheku). Probably, the IPA has become the wrong advisor [13].

The separation of power will be important for the future of Lesotho. The close ties between the royal family and the Roman Catholic Church should be cut, to achieve a clear separation of power [3]. No church leader, pastor, priest, or evangelist should be a member of a political party or take sides openly. This would help the church to raise her independent, prophetic voice [15], appealing to the people and the political authorities for justice, peace and keeping the constitution. It is now the time for people of integrity [15] to raise their voice with a message that hinders bloodshed. Free and fair elections for parliament, and probably even the affirmation of the king [6] with results accepted by everybody shall gain the trust of the nation. If Basotho overcome personal rivalries, seek the good of the nation and return to the values of Christianity, Lesotho has a chance for a better future.

\section{Consulted Literature}

Alt, A 1964. Das Königtum in den Reichen Israel und Juda, in: Kleine Schriften zur Geschichte des Volkes Israel. Volume II. 3rd edition. München: Beck'sche Verlagsbuchhandlung, 116-134.

Bright, J 1981. A History of Israel. 3rd Edition. Philadelphia: Westminster Press.

Donner, H 1984. Geschichte des Volkes Israel und seiner Nachbarn in Grundzügen 1. Grundrisse zum Alten Testament Band 4. Göttingen: Vandenhoeck \& Ruprecht.

Executive Committee of the Lesotho Evangelical Church 1998. We cannot remain silent. Maseru.

Fensham, F C \& Pienaar, D N 1989. Geskiedenis van ou Israel. 2nd Edition. Pretoria: Academica.

Gill, S 1993. A Short History of Lesotho. Morija: Morija Museum and Archives.

Lemche, N P 1988. Ancient Israel: a New History of Israelite Society. Sheffield: Sheffield Academic Press.

Leselinyana la Lesotho 30.11.1997. (Fortnightly newspaper). Morija: Morija Printing Works.

Machobane, L B B J 1978. Mohlomi: Doctor, Traveller and Sage. Journal of Southern African Historical Studies 2:5-27. 
-, 1990. Government and Change in Lesotho, 1800-1966: A Study of Political Institutions. London: Macmillan.

-, 1993. Christianization and African Response among the Barolong and Basotho, 1820-1890. ISAS Occasional Paper no. 7. Roma: National University of Lesotho.

Mohapeloa, J M 1985. From Mission to Church. Fifty Years of the Work of the Paris Evangelical Mission Society and the Lesotho Evangelical Church, 1933-1983. Morija: Morija Sesuto Book Depot.

Nelson, R D 1987. First and Second Kings (Interpretation), Louisville: John Knox.

Noth, M 1959. Geschichte Israels. Fourth Edition. Göttingen: Vandenhoeck \& Ruprecht.

Ploetz, C 1998 (ed.). Der grosse Ploetz. Darmstadt: Wissenschaftliche Buchgesellschaft.

Rice, G 1990. Nations under God. A Commentary on the Book of 1 Kings (International Theological Commentary), Grand Rapids: Eerdmans.

Soggin, J A 1984. A History of Israel: from the Beginnings to the bar Kochba Revolt, $A D$ 135. London: SCM Press.

Stuhlmacher, P 1997. Biblische Theologie des Neuen Testaments. Band 1. Grundlegung: von Jesus zu Paulus. 2nd Edition. Göttingen: Vandenhoeck \& Ruprecht. 